\title{
Toward a European Eco-label Brand for Residential Buildings: Holistic or By- Components Approaches?
}

\author{
Maria La Gennusa $^{1 *}$, Vincenzo Franzitta ${ }^{1}$, Giorgia Peri $^{1,2}$, Gianfranco Rizzo $^{1}$, Gianluca Scaccianoce $^{1}$ \\ ${ }^{1}$ Dipartimento di Ricerche Energetiche ed Ambientali, Università degli Studi di Palermo, Viale delle Scienze, 90128 \\ Palermo, Italy \\ ${ }^{2}$ Sustainable Engineering, Technische Universitaet Berlin, Office Z 1, Str. des 17. Juni 135, 10623 Berlin, Germany
}

\begin{abstract}
The Eco-label scheme is becoming ever more important in the environmental certification of products and services, especially in light of the recent ambitious aim of containing greenhouse emissions and improving the efficiency of utilizing energy sources. A recently-introduced hypothesis concerns the European Eco-label scheme relating to buildings, in the awareness that the construction industry is of primary importance to the whole economic and social life of states. This scheme should adopt an integrated approach to environmental problems and include construction, day-today management, and the possible disposal of building materials, throughout the life cycle of the building. In addition, in consideration of the particular scope of buildings, the main aim of this new scheme should also be to ensure enhanced conditions of comfort to the occupants of these buildings. In sight of this challenge, the building can be regarded as a summation of components (each of them characterized by a given level of environmental quality) or as a unique physical entity aimed at delivering suitable indoor condition to occupants with an assigned amount of primary energy and with a limited impact on the natural environment. In the paper, both approaches will be investigated, keeping also in mind the initiatives that are currently on the ground in the aim of establishing ecological criteria for the award of the community Eco-label for buildings.
\end{abstract}

Keywords: Energy and environmental performances of buildings; Indoor performance of buildings; Eco-label scheme; Holistic approach

\section{Introduction}

A European Union (EU) website [1] states that: "The EU Eco-label scheme is a voluntary scheme designed to encourage businesses to market products and services that are kinder to the environment and to make it easier for European consumers - including public and private purchasers - to identify them". This is one of the means by which the EU policy relating to the environment and business contributes to sustainable development. The EU Eco-label scheme (as laid down in Regulation (EC) No. 1980/2000 [2]) is now part of a wider approach to Integrated Product Policy (IPP), as part of the new Action Programme.

Within this framework, Europe is expending much effort at reducing energy consumption as regards the acclimatisation of buildings, towards improved controlling of environmental performance in the important sector of the construction industry. And the recently-released 2002/91/EC European Directive regarding the energy efficiency of buildings [3] is the most important example of this initiative to date. Following this Directive, Member States are currently introducing new technical standards which are profoundly modifying the design approaches to

\footnotetext{
* Corresponding author, FAX: +39 091484425, e-mail address: lagennusa@dream.unipa.it
} 
building efficiency. Moreover, several EU states offer citizens stimulating, financial instruments in promoting the adoption of more efficient building technologies and, particularly, the utilization of renewable energy resources. Apart from a substantial content regarding energy issues, the aforementioned EU Directive also contains various important references to the environmental performance of buildings, although this performance is essentially treated as a consequence of energy consumption.

This new approach is of increasing interest to technicians as it attempts to consider energy consumption and environmental performance of various types of dwellings in an integrated way

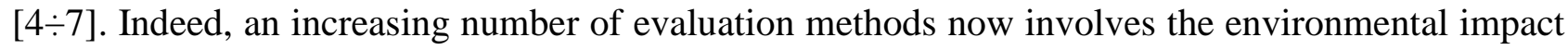
of the building throughout its entire life cycle (including traditional indicators of energy performance), thus taking into account not only the management phase, but also its construction and, in some cases, its demolishing.

Having been commissioned by the EU, the Italian Ministry for Economic Development (MAP) is engaged in defining criteria for applying the Eco-label brand to buildings ${ }^{\dagger}$. These criteria will be discussed here after a short review of the development of this scheme, together with a description of the proposed guidelines. This discussion will make reference to the framework and indicators of other schemes currently in force in similar sectors. Specifically, the EU tourist accommodation Ecolabel award scheme will be considered as the starting point for defining a similar scheme for buildings, due to its generally recognized feasibility and ease of application, also by nontechnicians. Based on existing similarities between tourist and residential buildings in terms of indicators of quality, this approach could dramatically simplify the search for new criteria regarding an advanced environmental brand for buildings.

After the analysis of this approach, belonging to a "by-components" methodology, the possibility of moving to a holistic approach will be argued by considering the building in terms of general performances, such as energy consumption, indoor comfort conditions, and environmental impacts.

\section{The need for energy and environment high-performances buildings}

The EU is making strenuous efforts aimed at reducing the energy consumption of air conditioning plants often used in buildings, and improving the general environmental performance of this important sector. In this regard, Directive 2002/91/EC [3] (the so-called EPB Directive), recently promulgated by the EU and accepted by the Member States, which concerns the energy efficiency of buildings, has introduced various extremely important elements for improving energy performance in the building sector. Specifically, with the introduction of the energy certification of buildings (an instrument expressly indicated in the Directive), an important step has been made toward enhancing this crucial economic sector.

Apart from the proposal rising from the EU, there exist several noteworthy examples of current initiatives concerning certification schemes at an international level: the United States of America

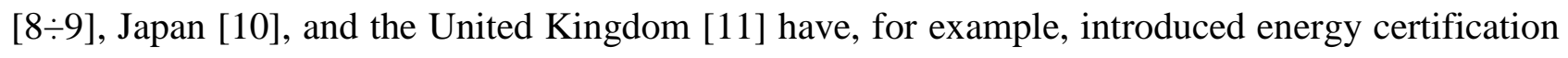
procedures for buildings. Moreover, there are numerous new standards relevant to evaluating the sustainability of buildings and, in particular, the materials involved [12] as well as standardizing bodies, such as the ISO and CEN. Moreover, it must be underlined that the European Union itself is

\footnotetext{
$\dagger$ Some of the authors of this article are Members of the Panel involved in this process.
} 
financing various projects for improving environmental quality levels in the building sector in the context of the VII Framework Programme.

In this dynamic context, possible approaches regarding the integrated assessment of quality buildings (i.e., energy consumption and environmental aspects) must not be overlooked. Indeed, a methodology based on the life cycle analysis of the materials, of which the building has been constructed, plays an important role by taking into account its envelope [13 14$]$. Recently, an innovative method for the environmental assessment of buildings was proposed: It is still based on the life cycle analysis approach, but it includes the concept of determined environmental burden [15], which analyzes the environmental impact exerted by the building on the territorial area in which it is located. Furthermore, it is important to mention the ecological footprint method [16], the aim of which is to define the impact made by human activities in terms of bio-productive and sea surface involved in the processes: It essentially represents the needed extent of biologically productive land and sea area able to cope with the resources utilized and the waste released by a given human population. This method is of great developmental promise, notwithstanding the substantial constraints of the availability of field data.

It is necessary to underline the fact that evaluating the energy efficiency of a building must not be separated from its indoor environmental performance that represents the actual final service delivered to occupants. Regarding the link between energy consumption and conditions of comfort, it is a widespread opinion that an energy saving scheme in managing buildings necessarily involves a reduction in indoor standards or, conversely, that an elevated level of comfort is attainable only by means of the use of highly sophisticated technological systems which, in turn, necessitate elevated amounts of primary energy sources. There is currently much debate among researchers and technicians as to whether high indoor environmental standards can be reached by consuming a sustainable amount of energy, thereby limiting the impact on the environment [17].

Anyway, the energy performance of a given building should be assessed only from an assigned level of the indoor conditions that satisfy the building occupants. This approach inevitably involves much careful thought regarding the levels of quality parameters for indoors; these in fact include

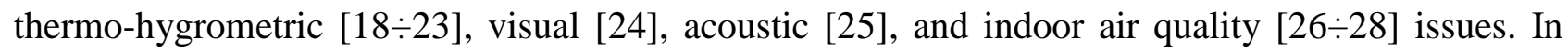
this regard, the EN 15251:2007 [29] Standard has been recently prescribed and this is an important instrument with which to make a generalized evaluation of the above-quoted indoor performance of a building.

\section{Developing European Eco-label criteria for buildings}

The Eco-label brand [2] is one of the more appropriate instruments by which the common policies of the EU are attempting to implement sustainable development in its Member States. An important feature of this instrument is that the products and services meeting required criteria are easily recognizable by consumers, through an EU logo that enables consumers to easily identify products which have a low environmental impact throughout their life cycle, in comparison with other products from the same category. Thus, consumers could make more informed and conscientious choices, especially that part of the purchasing public who are more sensitive to environmental problems. The Eco-label award is part of a wider approach by the EU, the main aim of which is to improve the environmental quality of products and services, reducing the environmental impact associated with each phase of the life cycle. The latter includes the extraction 
of raw materials, production, distribution and use, including waste management, which are all part of the Integrated Product Policy (IPP) [30]. The European ecologically-sensitive label was introduced in Europe in 1992 via the adoption of the 880/92 [31] European Regulation; it was subsequently updated with Regulation Number 1980 of 17 July 2000 [32].

The European Eco-label award could be particularly effective in the aim of defining a highquality performance brand for buildings. On the one hand, in fact, it is an instrument which considers the environmental impact of a product or service throughout its life cycle, by establishing relevant environmental criteria; on the other hand, it establishes a performance level of the product or service, thus determining requisites concerning the suitability for use in order to satisfy consumer needs.

Of course, it should be noted that a building represents a very particular type of product since it is aimed at guaranteeing an optimal (or, at least, acceptable) level of quality of an indoor environment (i.e., the thermo-hygrometric, indoor air quality, visual, and acoustic conditions). Thus, a building Eco-label should provide an excellent certification only for those products (buildings) which provide occupants with optimal conditions of comfort and, at the same time, exert a limited outdoor environmental impact. Moreover, the Eco-label would ensure a suitable energyefficient performance, as determined by Directive 2002/91/ EC.

The European Union entrusted the Italian Eco-label-Ecoaudit Committee and APAT (now ISPRA - Higher Institute for the Protection of the Environment and Environmental Research) with the task of identifying criteria for eligibility of the EU Eco-label award for buildings. The Ecolabel-Ecoaudit Committee is the official body which is qualified in the field of granting the European Eco-label brand in Italy. The latter has been assigned the role of country leader, and these two bodies are required to prepare criteria and methods with which to formulate an integrated and concise judgment regarding the overall performance of buildings.

The European Eco-label award for buildings can be usefully considered as a complementary tool [33] referring to the international work carried out by the ISO and the CEN. It could also play an important function as a reference tool for all the existing initiatives at national and international levels, such as the Italian tools "Casa Clima" [34] and the "Itaca" [35], Minergie [36], BREEM (Building Research Establishment Environmental Assessment Method) [11], LEED (Leadership in Energy and Environmental Design) [8], GBC (Green Building Challenge) [37], along with other proposed Eco-label schemes, such as the Nordic Swan [38] or the Catalonia Eco-label [39].

\section{An approach "by-components": new criteria of an Eco-label award for buildings}

The above-cited EU working group is developing a proposal for identifying new criteria to be considered for a Community Eco-label for buildings. The point of view from which the group approached the problem is a "by-components" vision of the building. This, in fact, apart some more general criteria applying to the site, consider the building as a summation of components, each of them exerting a given impact on the environment. In this way, the whole impact of the building is built-up by means of a bottom-up approach that accounts for the performances of the components of the building separately.

However, because a building can be much more complex than the summation of its components, it should be perceived and considered as a unique entity whose main purpose is to provide occupants with suitable comfort conditions, with low amount of energy consumption and with a 
limited impact on the environment. In this way, the building is analyzed by means of an integrated top-down approach.

In the following both approaches will be investigated on the basis of the initiatives currently on the ground.

The EU working group is currently acting to include the buildings in the product groups, which are candidates for achieving brand status. The Product Group Definition report, carried out by the working group has identified, as the object of the study, the Buildings considered in their entirety, as well as small houses, new or existing, public or private, used for residential purpose and for use as offices [40]. Regarding the categories of buildings to be considered, the following restrictions apply:

- various buildings, such as dwellings, are excluded;

- new buildings also include major refurbishments;

- existing buildings also include renovations;

- residential purpose means dwelling purpose;

- use as offices implies the use of the building for administrative, bureaucratic and educational activities of a public or private nature.

The first Working Report [33] essentially refers to indicators and environmental criteria proposed for European Green Public Procurement concerning construction materials, "in order to consider the issues mainly elaborated at European level for an evaluation of the building's environmental performance" [41]. Moreover, this Working Report pays attention to the assessment of the indoor environmental quality of buildings and a survey of the most relevant environmental certification schemes for buildings, which are currently available at the international level (Table 1). The Report also pays particular attention to the initiatives addressed to residential buildings; Table 2 deals with existing initiatives concerning sustainable buildings at the European level.

\section{Table 1}

The main environmental Certification schemes, selected by the EU working group for defining criteria to be included into the Eco-label scheme.

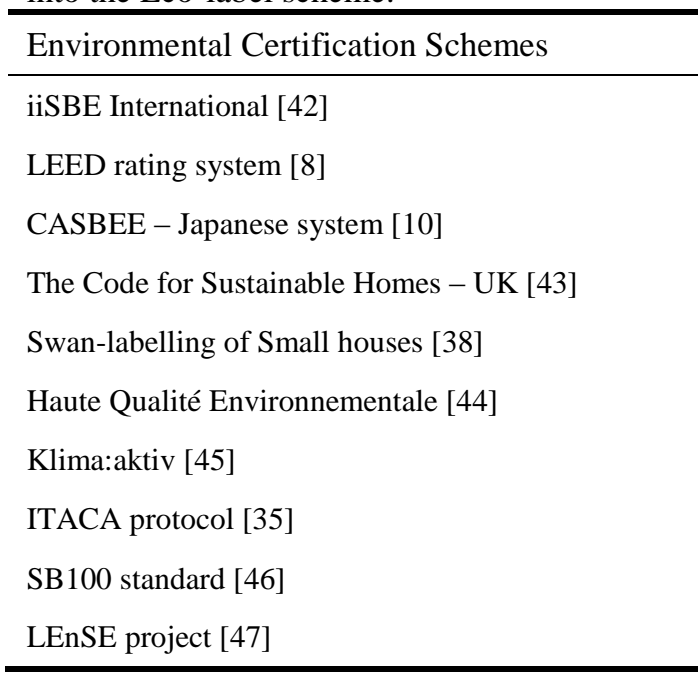


Table 2

In-force initiatives regarding sustainable buildings, analyzed by the EU working group.

The CEN350 Indicators [48]

The Construction Products Directive (CPD) [49]

The GPP - Green Public Procurement environmental criteria [41]

A possible range of criteria in terms of wording and thresholds definitions, focusing on future work, was introduced in the second Background Report (March 2009 [50]). The analyzed criteria, used within environmental certification schemes and existing initiatives concerning the sustainability of buildings, were classified for each issues/items reported in the first Background Report. 633 criteria were considered and they were subsequently allocated into classes (each of them subdivided into subclasses) concerning the main aspects for eligibility of an Eco-label award, that is:

- Class A: general issues, related to planning, project, the construction phase, the economy.

- Class B: environmental impact.

- Class C: resource consumption.

- Class D: suitability for use, comfort and safety issues.

Economic and safety issues were excluded as these are not directly related to environmental aspects. After this initial screening, 612 main issues were selected for consideration for the development of the EU Eco-label criteria for buildings. A second screening, based on considering how criteria belonging to different schemes can be classified (according to a simpler wording [Simplified Criteria]), produced a list of 208 simplified criteria.

Subsequently [51], another screening operation according to the frequency of simplified criteria was performed where, in addition to the most-used criteria selected, a number of suggested criteria (considered as significant from an environmental point of view) were also added by the working group. According to this step, 54 and 49 general criteria were finally selected respectively for new and existing buildings, as described in Tables $3 \mathrm{a}$ and $3 \mathrm{~b}$.

Table 3a

Selected criteria for the award of the Community Eco-label for new buildings.

\begin{tabular}{|c|c|c|}
\hline Issues & Mandatory criteria & Optional criteria \\
\hline Documentation & $\begin{array}{l}\text { 1. Building book } \\
\text { 2. Maintenance plan } \\
\text { 3. User's guide }\end{array}$ & 1. Other environmental certification systems \\
\hline $\begin{array}{l}\text { Planning - Project - } \\
\text { Construction }\end{array}$ & $\begin{array}{l}\text { 1. Design for disassembly, reuse, } \\
\text { recycling } \\
\text { 2. Social responsibility during the } \\
\text { construction phase }\end{array}$ & $\begin{array}{l}\text { 1. Site selection } \\
\text { 2. Experience of designer in environmental } \\
\text { construction } \\
\text { 3. Quality management system } \\
\text { 4. Building life cycle assessment (LCA) } \\
\text { 5. Environmental management system } \\
\text { 6. Construction and demolition waste } \\
\end{array}$ \\
\hline Impact on site & 1. Heat island & $\begin{array}{l}\text { 1. Green areas } \\
\text { 2. Heat island }\end{array}$ \\
\hline
\end{tabular}




\begin{tabular}{|c|c|c|}
\hline Materials & $\begin{array}{l}\text { 1. List of materials/products } \\
\text { 2. Wood based materials } \\
\text { 3. Wood materials } \\
\text { 4. Long life service materials } \\
\text { 5. Plastic materials }\end{array}$ & $\begin{array}{l}\text { 1. Energy embodied in materials/products } \\
\text { 2. Use or reuse of recycled materials/products } \\
\text { 3. Responsible sourcing of materials } \\
\text { 4. Use of material/products locally produced, non } \\
\text { structural functions } \\
\text { 5. Use of materials/products locally produced, } \\
\text { structural functions } \\
\text { 6. Labelled construction products } \\
\text { 7. } \mathrm{CO}_{2} \text { embodied in material/products } \\
\text { 8. Indoor and outdoor paints and varnishes, } \\
\text { coverings materials }\end{array}$ \\
\hline Energy & $\begin{array}{l}\text { 1. Energy efficiency, heating } \\
\text { 2. Renewable energy source }\end{array}$ & $\begin{array}{l}\text { 1. Energy efficiency, heating } \\
\text { 2. Energy efficiency, cooling and ventilation } \\
\text { 3. Energy efficiency, hot water }\end{array}$ \\
\hline $\begin{array}{l}\text { Water consumption } \\
\text { and management }\end{array}$ & $\begin{array}{l}\text { 1. Rainwater use } \\
\text { 2. Water saving systems }\end{array}$ & \\
\hline Waste management & 1. Recycling facilities & \\
\hline $\begin{array}{l}\text { Health and well- } \\
\text { being }\end{array}$ & $\begin{array}{l}\text { 1. Dust } \\
\text { 2. Radon } \\
\text { 3. Day lighting, common areas } \\
\text { 4. Lighting system control } \\
\text { 5. Day lighting, glare control } \\
\text { 6. Integrated indoor well being } \\
\text { 7. Day lighting, daylight factor } \\
\text { 8. Materials used for interiors } \\
\text { 9. VOC emissions in indoor environment }\end{array}$ & $\begin{array}{l}\text { 1. Domotic systems } \\
\text { 2. Natural ventilation }\end{array}$ \\
\hline $\begin{array}{l}\text { Operation and } \\
\text { Maintenance }\end{array}$ & & $\begin{array}{l}\text { 1. Internal partitions and walls } \\
\text { 2. Piping and cabling }\end{array}$ \\
\hline Facilities provided & $\begin{array}{l}\text { 1. Common TV antenna } \\
\text { 2. Transport facilities } \\
\text { 3. Cycle facilities }\end{array}$ & 1. Open spaces, green areas, common areas \\
\hline Fitness for use & 1. Test of building and equipment & \\
\hline
\end{tabular}

Table 3b

Selected criteria for the award of the Community Eco-label for existing buildings.

\begin{tabular}{|c|c|c|}
\hline Issues & Mandatory criteria & Optional criteria \\
\hline Documentation & $\begin{array}{l}\text { 1. Building book } \\
\text { 2. Maintenance plan } \\
\text { 3. User's guide }\end{array}$ & 1. Other environmental certification systems \\
\hline $\begin{array}{l}\text { Planning - Project - } \\
\text { Construction }\end{array}$ & & $\begin{array}{l}\text { 1. Design for disassembly, reuse, re cycling } \\
\text { 2. Building life cycle assessment (LCA) }\end{array}$ \\
\hline Impact on site & 1. Heat island & $\begin{array}{l}\text { 1. Green areas } \\
\text { 2. Heat island }\end{array}$ \\
\hline Materials & $\begin{array}{l}\text { 1. List of materials/products } \\
\text { 2. Long life service materials }\end{array}$ & $\begin{array}{l}\text { 1. Wood based materials } \\
\text { 2. Wood materials } \\
\text { 3. Use or reuse of recycled materials/products } \\
\text { 4. Responsible sourcing of materials } \\
\text { 5. Use of material/products locally produced, non } \\
\text { structural functions } \\
\text { 6. Use of materials/products locally produced, } \\
\text { structural functions } \\
\text { 7. Labelled construction products } \\
\text { 8. } \mathrm{CO}_{2} \text { embodied in material/products } \\
\text { 9. Indoor and outdoor paints and varnishes, } \\
\text { coverings materials } \\
\text { 10. Energy embodied in materials/products } \\
\text { 11. Plastic materials }\end{array}$ \\
\hline Energy & $\begin{array}{l}\text { 1. Energy efficiency, heating } \\
\text { 2. Renewable energy source }\end{array}$ & $\begin{array}{l}\text { 1. Energy efficiency, heating } \\
\text { 2. Energy efficiency, cooling and ventilation } \\
\text { 3. Energy efficiency, hot water }\end{array}$ \\
\hline $\begin{array}{l}\text { Water consumption } \\
\text { and management }\end{array}$ & 1. Water saving systems & 1. Rainwater use \\
\hline Waste management & 1. Recycling facilities & \\
\hline
\end{tabular}




\begin{tabular}{llll}
\hline & 1. Dust & \\
& 2. Radon & \\
Health and well- & 3. Day lighting, common areas & 1. Domotic systems \\
being & 4. Lighting system control & 2. Natural ventilation \\
& 5. Day lighting, glare control & 3. Materials used for interior \\
& 6. Integrated indoor well being & 4. VOC emissions in indoor environments \\
\hline & 7. Day lighting, daylight factor & 1. Transport facilities \\
Facilities provided & 1. Common TV antenna & 2. Cycle facilities \\
& 1. Accessibility & 3. Open spaces, green areas \\
\hline Fitness for use & 2. Test of building and equipment & \\
\hline Operation and & & & 1. Internal partitions \\
Maintenance & & 2. Piping and cabling \\
\hline
\end{tabular}

In order to be awarded the Community Eco-label, a building shall fall within the product group "buildings"; it also shall comply with each of the mandatory criteria (Table $3 \mathrm{a}$ and $3 \mathrm{~b}$ ) and shall comply "with a sufficient number" of the optional criteria.

This scheme is obviously important in order of assessing a general scheme for attributing an environmental excellence label to a building. Anyway, at the state, some problems do arise.

First of all, each general criterion (mandatory as well optional) is declined into a certain number of indicators, in this way, enlarging the total number of parameters to be managed by technicians. This would clearly make the application of this Eco-label scheme too complicated and time consuming.

Moreover, the meaning of the expression "a sufficient number of optional criteria" is not clear at the moment: It's evident that people need to know the exact number of criteria to be applied in order to avoid discretional interpretations of the scheme.

The last point to analyzed here is the score system and the threshold level that a building must score in order to be awarded with the Eco-label brand. In the proposed scheme, the maximum score attainable for each criterion, both for new and existing buildings, is indicated. At present, a common threshold level of 85 points has been proposed for both categories of buildings: These points are the summation of the result for mandatory and optional criteria, as described in Table 4.

Table 4

Score system for the proposed Eco-label for buildings.

\begin{tabular}{lccccccc}
\hline \multirow{2}{*}{$\begin{array}{l}\text { Type of } \\
\text { building }\end{array}$} & \multicolumn{2}{c}{ Total criteria } & \multicolumn{2}{c}{ Mandatory criteria } & \multicolumn{3}{c}{ Optional criteria } \\
& $\begin{array}{c}\text { No. of } \\
\text { criteria }\end{array}$ & $\begin{array}{c}\text { Maximum } \\
\text { score }\end{array}$ & $\begin{array}{c}\text { No. of } \\
\text { criteria }\end{array}$ & $\begin{array}{c}\text { Maximum } \\
\text { score }\end{array}$ & $\begin{array}{c}\text { No. of } \\
\text { criteria }\end{array}$ & $\begin{array}{c}\text { Maximum } \\
\text { score }\end{array}$ & $\begin{array}{c}\text { Threshold } \\
\text { score }\end{array}$ \\
\hline New & 54 & 117 & 29 & 61 & 25 & 56 & 24 \\
Existing & 49 & 106 & 20 & 41 & 29 & 65 & 44 \\
\hline
\end{tabular}

Although a strong effort has been produced in order to single out a general scheme for points and scores to be attributed to each criterion, it is evident that the approach does appear still complex and that further research must be undergone before this Eco-label scheme enters into force. 


\section{A holistic approach}

The previous described approaches belong to a "by-components" vision of the building, in the sense that its whole performance is seen as the summation of the single performances of each component that comprises it.

Independently from the considerations concerning the appropriateness of this approach, the above reported description indicates that some serious problems do arise in applying such schemes. They, in fact, require a large number of information about the building (most of them difficultly achievable) and are based on complex and time-spending procedures. Moreover, they show a deep lack in the acceptability of a scale of scores to be attributed to the single indicators, to the weights by means of which each indicator concurs to the definition of the whole score of a building and, finally, to the benchmark of the values of the building score for the awarding of the Eco-label brand.

However, apart from these difficulties (representing an important constraint for the adoption of the above described "by-components" approach), it must be observed that a building should be more appropriately considered as a unique entity whose goal is to provide people with sufficiently high level of indoor conditions.

On the other hand, the increasing awareness regarding the importance of analysis tool for the integrated assessment of the energy, environmental, and comfort performance of buildings leads us to question whether it is possible to refer to a holistic procedure for assessing the whole building quality, including outdoor and indoor environmental performances. In other words, the Community Eco-label should be simply assigned to buildings whose energy, indoor, and environmental performances exceed well-recognized levels (Fig. 1).

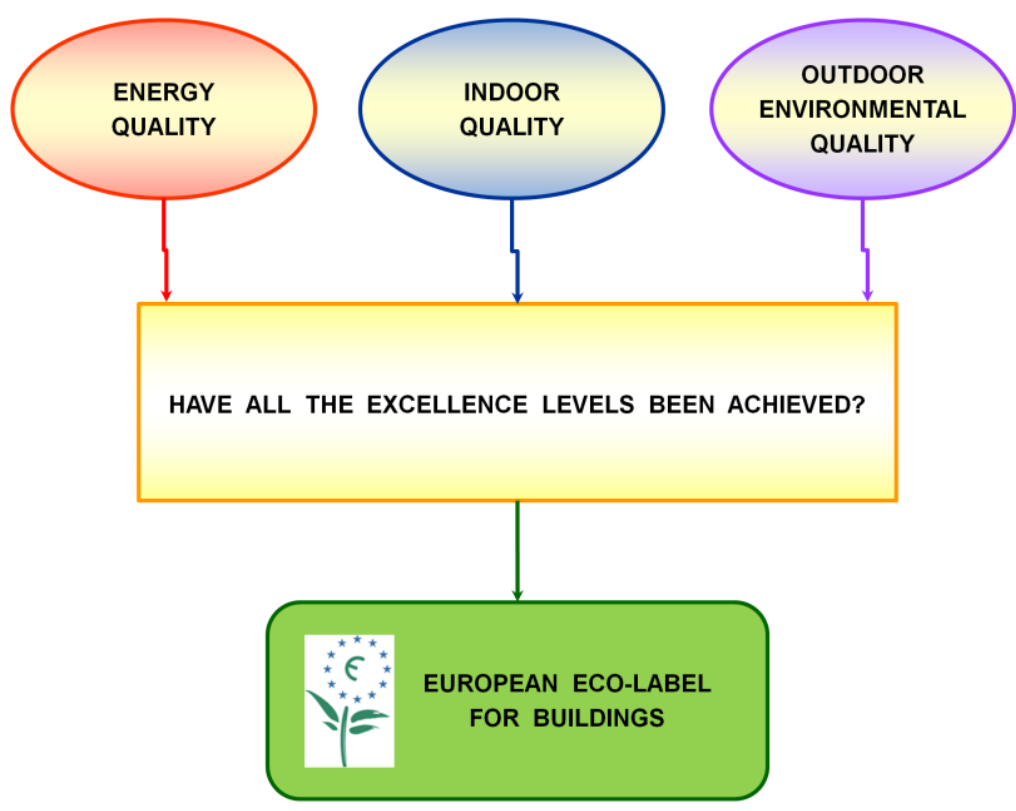

Fig. 1. An integrated approach for an EU Eco-label building award.

In this aim, three main aspects of this generalized approach will be investigated in the following, that is, energy, indoor, and environmental performances of buildings. 


\subsection{Energy performances}

Much attention has recently focused on the energy requirements and overall performance of buildings, particularly in industrialized countries; two reasons for this are posited here: on the one hand, the construction sector is a high energy consumer (in Italy, for example, approximately $45 \%$ of total primary energy is attributed this sector [52]); on the other hand, and given that many people spend much of their lives indoors, it is clear that quality buildings play a part in improving the quality of life and working conditions. Moreover, the management of buildings, as well as its entire production chain, is a significant source of air pollutant emissions in urban centers. These important issues are a significant push factor toward updating the technical regulations concerning the internal and external energy performance of buildings and their environmental characteristics. The wellknown 2002/91/CE European Directive regarding the energy performance of buildings recently brought into force by Member States represents the most important proposals in the field of construction.

As that, a Community Eco-label would also ensure a suitable energy-efficient performance of buildings, as determined by Directive 2002/91/ EC (EPB).

It is well known that the EPB Directive has been received and implemented by the Member States in different ways, but all national schemes [53] introduce a classification of the energy performances of buildings in terms of primary energy required for climatization purposes, domestic hot water production, and lighting: This energy is expressed by means of a synthetic parameter that indicates the seasonal primary energy consumption by unity of surface area of the floor building (or by unity of its volume).

Although many differences can be found in the benchmarking schemes [54] and labelling methodologies [55] in each different country, the first two classes include buildings with a very low consumption of energy, so that they could be selected as the minimum requirements for a building in order to be awarded an Eco-label brand, with reference to the energy performances. More in details, new buildings should comply with the first energy class and existing buildings with the second energy class of the pertinent country.

In addition, a building characterized by high quality of the energy performance should utilize a significant amount of energy coming from renewable sources for producing electricity or heat. The recent Italian legislation [56], for example, indicated for new buildings a mandatory percentage of $30 \%$ of electric energy produced by photovoltaic systems and a minimum percentage of $50 \%$ for DHW produced by solar thermal panels of renewable energy. Although these values seem too high for practical applications (they are, in fact, subject to reconsideration), they signal an important trend in the use of RES in buildings that must be embodied in an excellence brand such as the European Eco-label award.

\subsection{Indoor performances}

Although Directive 2002/91/EC has accelerated the debate regarding the energy efficiency of buildings, it represents only an initial step toward the assessment of their general quality. It is now necessary to extend the analysis of the evaluation of buildings by directly involving the 
environmental issues in the various phases of the design, construction, and management of buildings, also considering the level of indoor performance for human use.

In general, aspects relating the indoor performance of a building should be verified and checked prior to any energy and environmental analysis. Thus, the attainment of indoor requirements should be a necessary condition of eligibility for the Eco-label award. As that, it could be hypothesized that a simple Eco-label eligibility scheme for buildings will initially satisfy a given level of indoor performance.

On the basis of the current status of technical regulations, it seems quite reasonable to use the recently released EN 15251 standard [29] with the aim of identifying suitable criteria concerning the level of the environmental quality of buildings. This quality must be sufficiently high in order to be incorporated in an advanced quality brand, as is the EU Eco-label. The EN standard comprises various criteria and threshold values with the purpose of assigning a quality level to an indoor environment in relation to: (i) thermo-hygrometric; (ii) visual; (iii) acoustic; and (iv) indoor air quality conditions.

As far as the indoor performance of this building is in context, on the purpose of the singling out of acceptable requirements for the attribution of the EU Eco-label award to single rooms of new buildings, an indoor environment can be acknowledged as candidate for this excellence award if the issues of the indoor performance described by the EN 15251 [29] and referring to thermal environment and indoor air quality and ventilation rates fall into the Category II, for which a normal level of expectation of people is foreseen. It should be used for new buildings and renovations.

On the other hand, for existing buildings, an indoor environment is acknowledged as candidate for the Eco-label award if the cited two issues (thermal environment and indoor air quality and ventilation rates) fall into Category III, for which an acceptable moderate level of expectation is foreseen by people.

Table 5 reports the explanation of the features of the four categories considered for indoor performances within the EN 15251.

Table 5

Description of the applicability of the categories used.

\begin{tabular}{cl}
\hline Category & \multicolumn{1}{c}{ Explanation } \\
\hline I & $\begin{array}{l}\text { High level of expectation and is recommended for spaces occupied by very } \\
\text { sensitive and fragile persons with special requirements like handicapped, sick, } \\
\text { very young children, and elderly persons }\end{array}$ \\
& $\begin{array}{l}\text { Normal level of expectation and should be used for new buildings and } \\
\text { II }\end{array}$ \\
III & $\begin{array}{l}\text { An acceptable, moderate level of expectation and may be used for existing } \\
\text { buildings }\end{array}$ \\
& $\begin{array}{l}\text { Values outside the criteria for the above categories. This category should only be } \\
\text { accepted for a limited part of the year }\end{array}$ \\
\hline
\end{tabular}


By summarizing, recommended criteria found in the EN 15251 standard to be utilized, as a first attempt, for defining the indoor parameters for the EU Eco-label to buildings, are reported in Table 6 for new buildings (and renovation) and for existing buildings.

Table 6

Indoor pre-requirements [29] that a new or existing residential building should satisfy in order to obtain the Eco-label.

\begin{tabular}{|c|c|c|c|c|c|c|}
\hline $\begin{array}{l}\text { ASPECTS OF } \\
\text { COMFORT }\end{array}$ & \multicolumn{3}{|c|}{ NEW BUILDINGS } & \multicolumn{3}{|c|}{ EXISTING BUILDINGS } \\
\hline \multirow{2}{*}{$\begin{array}{l}\text { Thermal } \\
\text { environment }\end{array}$} & $\begin{array}{l}\text { Mechanical heated } \\
\text { and cooled } \\
\text { buildings }\end{array}$ & $\begin{array}{l}\mathrm{PPD}<10 \% \\
-0.5<\mathrm{PMV}<+0.5\end{array}$ & $\mathrm{~T}_{\mathrm{o}}>20^{\circ} \mathrm{C}$ & $\begin{array}{l}\text { Mechanical heated } \\
\text { and cooled } \\
\text { buildings }\end{array}$ & $\begin{array}{l}\mathrm{PPD}<15 \% \\
-0.7<\mathrm{PMV}<+0.7\end{array}$ & $\mathrm{~T}_{\mathrm{o}}<26^{\circ} \mathrm{C}$ \\
\hline & $\begin{array}{l}\text { Buildings without } \\
\text { mechanical cooling } \\
\text { systems }\end{array}$ & \multicolumn{2}{|c|}{$\begin{array}{l}0.33 \Theta_{\mathrm{rm}}+18.8-3<\Theta_{\mathrm{I}}<0.33 \Theta_{\mathrm{rm}}+18.8+3 \\
\text { Indicator: operative temperature } \Theta_{\mathrm{I}}\end{array}$} & $\begin{array}{l}\text { Buildings without } \\
\text { mechanical cooling } \\
\text { systems }\end{array}$ & \multicolumn{2}{|c|}{$\begin{array}{l}0.33 \Theta_{\mathrm{rm}}+18.8-4<\Theta_{\mathrm{I}}<0.33 \Theta_{\mathrm{rm}}+18.8+4 \\
\text { Indicator: operative temperature } \Theta_{\mathrm{I}}\end{array}$} \\
\hline \multirow{2}{*}{$\begin{array}{l}\text { Indoor air } \\
\text { quality and } \\
\text { ventilation rates }\end{array}$} & $\begin{array}{l}\text { Ventilation during } \\
\text { occupied hours }\end{array}$ & \multicolumn{2}{|c|}{$\begin{array}{l}\text { air change rate }>0.42 \mathrm{~m}^{2} \text { floor area } \\
\text { air change rate per hour }>0.6\end{array}$} & $\begin{array}{l}\text { Ventilation during } \\
\text { occupied hours }\end{array}$ & \multicolumn{2}{|c|}{$\begin{array}{l}\text { air change rate }>0.35 \mathrm{~m}^{2} \text { floor area } \\
\text { air change rate per hour }>0.5\end{array}$} \\
\hline & $\begin{array}{l}\text { Ventilation during } \\
\text { non-occupied hours }\end{array}$ & \multicolumn{2}{|l|}{0.05 to $0.11 / \mathrm{s} \mathrm{m}^{2}$} & $\begin{array}{l}\text { Ventilation during } \\
\text { non-occupied hours }\end{array}$ & \multicolumn{2}{|l|}{0.05 to $0.1 \mathrm{l} / \mathrm{s} \mathrm{m}^{2}$} \\
\hline $\begin{array}{l}\text { Humidification } \\
\text { and } \\
\text { dehumidification }\end{array}$ & \multicolumn{3}{|c|}{$\begin{array}{l}\text { Design relative humidity for dehumidification: } 60 \% \\
\text { Design relative humidity for humidification: } 25 \%\end{array}$} & \multicolumn{3}{|c|}{$\begin{array}{l}\text { Design relative humidity for dehumidification:70\% } \\
\text { Design relative humidity for dehumidification: } 20 \%\end{array}$} \\
\hline Lighting & \multicolumn{3}{|c|}{$\begin{array}{l}\text { Values of Table D.1 of EN } 15251 \text { [35] for maintained } \\
\text { illuminance }\left(\mathrm{E}_{\mathrm{m}}\right) \text {, colour rendering index (Ra.) and unified } \\
\text { glare rating (UGR) }\end{array}$} & \multicolumn{3}{|c|}{$\begin{array}{l}\text { The illuminance shall be measured on the task area to } \\
\text { conform to values recommended in EN 12464-1 at all } \\
\text { operational times. }\end{array}$} \\
\hline Noise & \multicolumn{3}{|c|}{$\begin{array}{l}\text { A-weighted sound pressure level }(\mathrm{dB}(\mathrm{A})) \\
\text { Living room: } 25 \text { to } 40 \\
\text { Bedroom: } 25 \text { to } 35\end{array}$} & \multicolumn{3}{|c|}{$\begin{array}{l}\text { A-weighted sound pressure level }(\mathrm{dB}(\mathrm{A})) \\
\text { Living room: } 25 \text { to } 40 \\
\text { Bedroom: } 25 \text { to } 35\end{array}$} \\
\hline
\end{tabular}

\subsection{Environmental performances}

It is also appropriate to take into account the fact that buildings, with their materials and technological systems, exert a particular impact on the external environment throughout the whole life cycle. They are typical of the various phases of the production cycle of the materials involved and building use, namely, construction, use/management, and demolishing. Generally, environmental impacts of buildings, apart from the use of energy sources, can be tentatively classified within these main categories: gaseous emissions, particulate matters, use of freshwater, solid waste, and wastewater. All these issues, in turn, can be usefully considered as relevant for the evaluation of the sustainability in constructions.

In this field, the most important Technical Committee in Europe can be considered the CEN/TC350 ("Sustainability of construction works"). It is aiming at the [57] "development of voluntary horizontal standardized methods for the assessment of the sustainability aspects of new and existing construction works and for standards for the environmental product declaration of construction products as part of implementation of European policy." The sustainability assessment is considered in terms of:

-Environmental performance (Mandate M/350).

- Social performance.

-Economic performance.

Life Cycle Analysis [58] is assumed by the CEN/TC350 as the most effective tool of analysis, as it encounters the whole impact through all the phases of a building's useful life cycle [59]. Within 
this Committee, the CEN/TC 350/WG 3 "Product level," is charged for producing some documents referring to the Environmental Product Declaration for buildings, on the basis of the ISO Standards 21930 [60], 14025 [61], 14040 [62], and 14044 [63].

The CEN/TC350 project is particularly significant in that it takes expressly into account the needs of the policies related to the construction products, including the Eco-label.

Moreover, it considers (Table 7) a group of input/output environmental indicators [57] that can be importantly utilized as criteria for attributing a building with an Eco-label award.

Table 7

Group of input/output environmental indicators as suggested by CEN/TC 350.

\begin{tabular}{lll}
\hline $\begin{array}{l}\text { Output indicators for } \\
\text { environmental impacts }\end{array}$ & $\begin{array}{l}\text { Input indicators for material and } \\
\text { energy flows }\end{array}$ & $\begin{array}{l}\text { Output indicators for material and } \\
\text { energy flows }\end{array}$ \\
\hline - Climate change. & & \\
- Destruction of the stratospheric & - Use of non-renewable materials. & - Use of renewable materials. \\
ozone layer. & - Use of non-renewable primary for recycling. \\
- Acidification of land and water & energy. & - Materials for energy recovery. \\
resources. & - Use of renewable primary & disposal. \\
- Eutrophication. & energy. & - Hazardous waste to disposal. \\
- Formation of ground level & $\bullet$ Use of freshwater resources. \\
ozone. & & \\
\hline
\end{tabular}

On the ground of the previous considerations, within an integrated approach aimed at the environmental assessment of a building, one can adopt the framework proposed by the CEN/TC 350 , with a specific attention to the suggested input/output indicators. In order of awarding a building with an Eco-label brand, it should achieve, for each indicator, the excellence levels foreseen within the national standards of the country to which the building belongs.

This, on one hand, could make easier the application on an Eco-label scheme (by referring to existing regulations and standards); on the other hand, it would implicitly consider the differences that exist among various countries that, in a considerable part, are encountered in the national technical regulations.

\section{An operative proposal for an integrated approach to Eco-label for buildings}

The current approach aiming to formulate a European Eco-label scheme in awarding the environmental quality of buildings is based on the consideration that the building is a sum of its parts, parts which perform different functions and which can be examined and ranked independently of each other. In such a scheme, a score would be attributed to each component regarding the function level, which each component can ensure. In accordance with this by-components approach, the Eco-label award could be assigned to buildings comprising, for example, a minimum number of components, which are characterized by scores higher than those representing the benchmark for each of the components.

Currently, this approach appears complex as it could lead to an excessive number of parameters relating to any given building. Consequently, a holistic approach to the challenge of identifying criteria regarding the Eco-label has also been proposed. This considers the building as one entity whose purpose is mainly to provide conditions of comfort to the occupants with limited amounts of 
energy consumption and a low environmental impact. Such an approach would limit the number of requisite criteria and the Eco-label brand could be simply assigned by verifying the attainment of established functional requisites in each of the three quoted areas, that is, the comfort of people, energy consumption, and environmental impact.

Fig. 2 shows a simple logic diagram describing the holistic approach, detailing the scheme of Fig. 1. It only bestows the brand if the building satisfies all quality judgments in the three considered issues, that is, energy performance (assessed in accordance with the 2002/91/EC European Directive), indoor performance (assessed in accordance with EN 15251), and environmental performance (assessed via Life Cycle Analysis procedures).

More in detail, and referring to the above reported considerations, a new building (or existing) can be awarded an Eco-label brand if it belongs to the first class (or second class for existing buildings) of the energy performances, referring to the pertinent country technical standards that receive the EBP Directive. In addition, the building should utilize a given amount of energy, coming from renewable sources, for producing electricity or heat.

Moreover, a building can be considered for the Eco-label award if it complies with the parameters of Table 6 with respect to the indoor performances.

Finally, a building aspiring to be attributed an Eco-label award should fulfil the input/output group of parameters suggested by the CEN/TC 350 working committee, at the levels foreseen by the pertinent country technical standards.

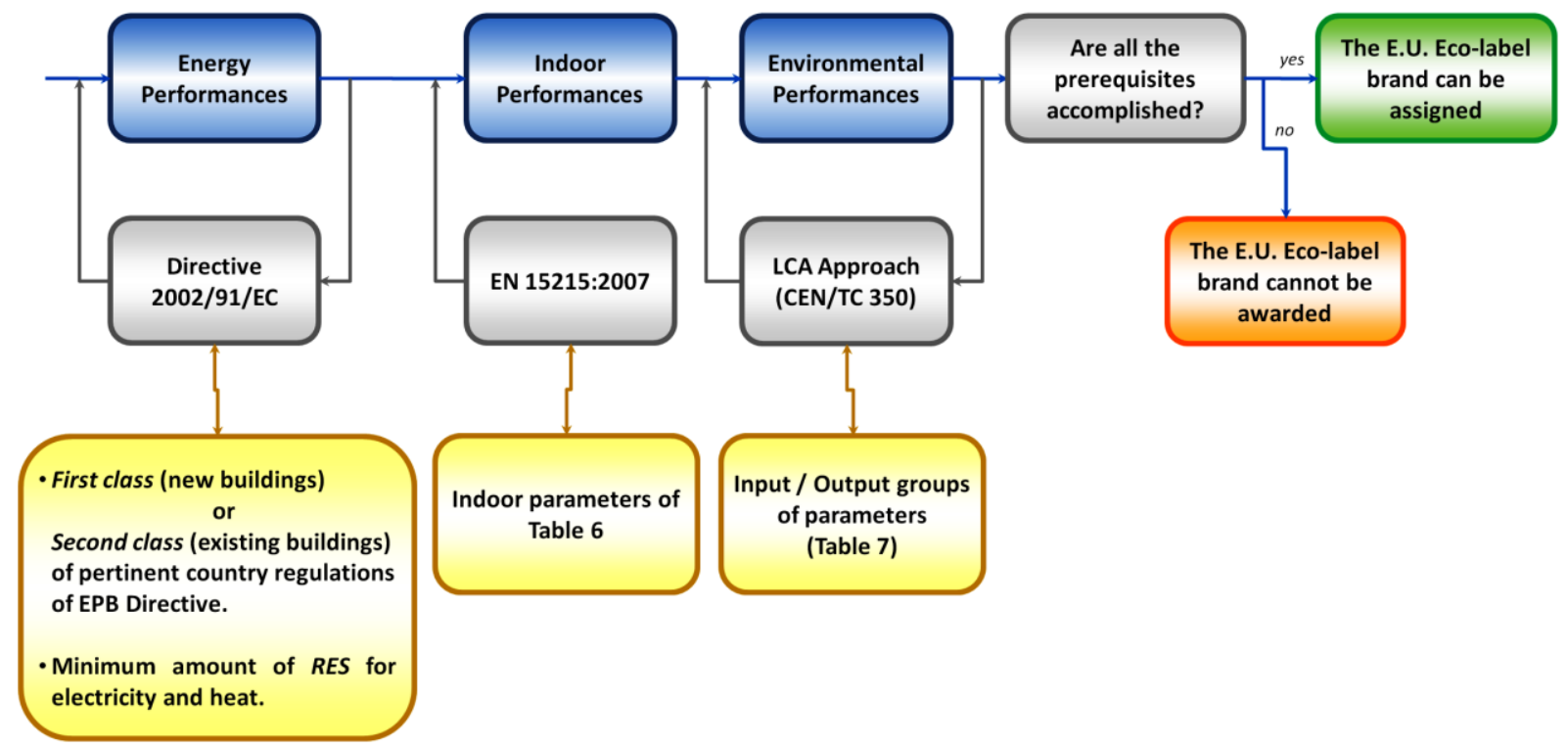

Fig. 2. Logic diagram of a holistic approach for bestowing an Eco-label award to buildings.

\section{Conclusion}

The path toward the definition of innovative criteria for an environmental quality brand for buildings is long and arduous, although the current level of research is promising. The efforts currently being carried out on an international level toward the assessment of an Eco-labelling scheme for buildings would appear to be fully justified as they would assist in the development of a 
new and important tool for designers, planners, and technicians involved in the development of a new generation of sustainable buildings.

The European-led approach for singling out criteria for an Eco-label brand of buildings can be qualified as a by-components one, where the building-plant system is considered as a summation of distinct parts and functions. This will likely lead to the establishment of a high number of criteria, in order to properly take into account the various aspects of the quality of a building. This can represent a serious constraint in the process of facilitating the spread of the Eco-label brand among technicians.

In this work, an alternative approach has been presented, that considers buildings as a whole system whose main goals are providing people with high indoor comfort conditions, by utilizing a moderate quantity of energy and with a limited impact on environment and on the depletion of resources. This vision leads to a holistic approach that has been described in the previous sections.

Fig. 2 illustrates in a synthetic manner the scheme of application of such approach.

Compared with the "by-components" approach, the holistic procedure seems easier to be applied because it relies on general categories of performance rather than on a gathering of single indicators. Moreover, it can be easily received within the framework of the technical set of laws because it is constituted by existing regulations. As a consequence, this approach is capable of producing more rapidly positive effects in terms of reduction of pollutant releases and in terms of an increasing efficiency in the use of energy and resources.

It is evident that this method cannot be considered a definitive one: On the contrary, along with the enhancement of the technical standards and with the increasing availability of data concerning the environmental impacts of the building materials, it will have to undergo revisions and changes. Nevertheless, provided that it relies on existing standards and regulations, this method embodies, at present, the best available performances of buildings, making it possible an immediate and effective application.

\section{References}

[1] Commission of the European Communities network. See: http://ec.europa.eu/environment/ecolabel/ (accessed May 2009).

[2] Regulation (EC) No 1980/2000 of the European Parliament and of the Council of 17 July 2000 on a revised Community Eco-label Award Scheme.

[3] Directive 2002/91/EC of the European Parliament and of the Council of 16 December 2002 on the energy performance of buildings. Official Journal of the European Communities L 1/65, 4.1.2003.

[4] Chirarattananon S, Chaiwiwatworakul P, Hien VD, Rakkwamsuk P, Kubaha K. Assessment of energy savings from the revised building energy code of Thailand. Energy 2010;35(4):1741-1753.

[5] Zhu L, Hurt R, Correa D, Boehm R. Comprehensive energy and economic analyses on a zero energy house versus a conventional house. Energy 2009;34(9):1043-1053.

[6] Radhi H. Can envelope codes reduce electricity and $\mathrm{CO}_{2}$ emissions in different types of buildings in the hot climate of Bahrain? Energy 2009;34(2):205-215.

[7] Wen-Shing L. Benchmarking the energy performance for cooling purposes in buildings using a novel index -total performance of energy for cooling purposes. Energy 2010;35(1):50-54.

[8] U.S. Green Building Council (USGBC), LEED (Leadership in Energy and Environmental Design). Network: www.usgbc.org (accessed May 2009).

[9] Cidell J, Beata A. Spatial variation among green building certification categories: Does place matter? Landscape and Urban Planning 2009;91:142-151. 
[10] Japan GreenBuild Council (JaGBC) and Japan Sustainable Building Consortium (JSBC), CASBEE (Comprehensive Assessment System for Building Environmental Efficiency). Network: http://www.ibec.or.jp/CASBEE/english/index.htm (accessed May 2009).

[11] Building Research Establishment, BREEAM (Building Research Establishment Environmental Assessment Method. Network: http://www.breeam.org/index.jsp (accessed May 2009).

[12] See, for example, the ASTM International Standards for Sustainability in Building (3rd Edition, ISBN13: 978-08031-5615-9, http://www.astm.org), and the BSI British Standards on Construction Materials (http://www.bsiglobal.com/en/Standards-and-Publications/Industry-Sectors/Building-and-Construction/Construction-Materials/).

[13] Erlandson M, Borg M. Generic LCA-methodology applicable for building, construction and operation service Today practice and development needs. Building and Environment 2003;38(7):919-38.

[14] Goedkoop M, Spriensma R. The Eco-indicator 99. A damage oriented method for life cycle assessment. Methodology report. Amersfoort, Netherlands, Prè Consultants, 2001.

[15] Li Z. A new life cycle impact assessment approach for buildings. Building and Environment, 2006;41:14141422.

[16] Wackernagel M, W. Rees. Our Ecological Footprint. Reducing Human Impact on the Earth. Gabriola Island, British Columbia, Canada: New Society Publishers; 1996.

[17] Olesen BW. The philosophy behind EN15251: Indoor Environmental Criteria for Design and Calculation of Energy Performance of Buildings. Energy and Buildings, 2007;39(7):740-749.

[18] ANSI/ASHRAE Standard 55:2004. Thermal Environmental Conditions for Human Occupancy. Atlanta, GA: American Society of Heating, Refrigerating and Air-Conditioning Engineers, 2004.

[19] ISO 7730:2005. Ergonomics of the Thermal Environment e Analytical determination and Interpretation of Thermal Comfort using Calculation of the PMV and PPD Indices and Local Thermal Comfort Criteria. Geneva: International Organization for Standardization, 2005.

[20] ISO 7726:1998. Ergonomics of the Thermal Environment e Instruments for Measuring Physical Quantities. Geneva: International Organization for Standardization, 1998.

[21] Fanger PO. Thermal Comfort. Copenhagen: Danish Technical Press; 1970.

[22] DeDear. Thermal Comfort in Practice. Indoor Air Journal, 2004;14(7):32-39.

[23] McCartney KJ, Nicol JF. Developing an Adaptive Control Algorithm for Europe: Results of the SCATs Project. Energy and Buildings 2002;34(6):623-635.

[24] EN 12464:2002. Light and lighting - Lighting of work places- Part 1: Indoor work Places. Brussels: European Committee for Standardization, 2002.

[25] EN 12354-1/6. Series of Building Acoustics Standards. Brussels: European Committee for Standardization, 2000-2009.

[26] ISO DIS 16814:2005. Building environment design — Indoor air quality — Methods of expressing the quality of indoor air for human occupancy. Geneva: International Organization for Standardization, 2005.

[27] ASHRAE Standard 62-2001. Ventilation for Acceptable Air Quality. Atlanta, GA: American Society of Heating, Refrigerating and Air-Conditioning Engineers, 2004.

[28] CEN CR 1752:2002. Ventilation for buildings - Design criteria for the indoor environment. Brussels: European Committee for Standardization, 2002.

[29] EN 15251:2007. Indoor environmental input parameters for design and assessment of energy performance of buildings addressing indoor air quality, thermal environment, lighting and acoustics. Brussels: European Committee for Standardization, 2007.

[30] Commission of the European Communities, Green Paper on Integrated Product Policy COM(2001)68 final, Brussels, 07.02.2001.

[31] The Council of the European Communities, Council Regulation (EEC) 880/92 of 23 March 1992 on a Community eco-label award scheme. Official Journal of European Communities No L 99/1, Brussels 11.04.1992.

[32] The Council of the European Communities, Regulation (EC) No 1980/2000 of the European Parliament and of the Council of 17 July 2000 on a revised Community Eco-label Award Scheme. Official Journal of the European Communities L 237/1, Brussels 21.9.2000.

[33] APAT. Study for the development of European Eco-label criteria for buildings - Preliminary Report. April 2008, unpublished report.

[34] KlimaHaus - CasaClima. Network: http://www. casaclima.info (accessed May 2009). 
[35] ITACA Protocol. ITACA (Istituto per l'innovazione e Trasparenza degli Appalti e la Compatibilità Ambientale) network: http://www.itaca.org (accessed May 2009).

[36] MINERGIE® website: http://www.minergie.ch/home_it.html (accessed May 2009).

[37] GBC, Green Building Challenge. Website: http://greenbuilding.ca/ (accessed May 2009).

[38] Nordic Ecolabelling, Swan Labelling of Small Houses. Website: http://www.svanen.nu/Default.aspx?tabName=StartPage (accessed May 2009).

[39] Randa Group, Development and implementation of a Marketing and promotion strategy for the Eco-label in Catalonia, Spain (Ecolabel-cat). Final Report, February 2003, Barcelona, Spain.

[40] ISPRA (Italian Institute for Environmental Protection and Research), Product Group Definition Report. Ad Hoc Working Group Meeting, August 2008. Website: http://www.apat.gov.it/certificazioni/site/itIT/Ecolabel/Documentazione/Prodotti/

[41] European Commission, Buying green! A handbook on environmental public procurement. ISBN 92-894-8117-x. Luxembourg: European Communities, 2004.

[42] iiSBE (The International Initiative for a Sustainable Built Environment). Website: http://www.iisbe.org (accessed May 2009).

[43] Department for Communities and Local Government, Code for Sustainable Homes - A step-change in sustainable home building practice. December 2006. Website: www.communities.gov.uk (accessed May 2009).

[44] Association pour la Haute Qualité Environnementale (ASSOHQE), Haute Qualité Environnementale (HQE) Standard, Paris. Website: http: www. assohqe.org (accessed May 2009).

[45] Austrian Federal Ministry of Agriculture, Forestry, Environment and Water Management, Klima:aktiv. Website: www.klimaaktiv.at (accessed May 2009).

[46] SB100 (Sustainable Buildings with 100 actions). Certification system by the National Association of Bioecological Architecture (ANAB). Website: http://www.anab.it (accessed May 2009).

[47] LEnSE project. Website: http://www.lensebuildings.com/index.asp?sid=1 (accessed May 2009).

[48] ISPRA (Italian Institute for Environmental Protection and Research), Study for the development of European Eco-label criteria for buildings, First background report, Revised version - January 2009.

[49] Council Directive 89/106/EEC (The Construction Products Directive) of 21 December 1988 on the approximation of laws, regulations and administrative provisions of the Member States relating to construction products (89/106/EEC) (OJ L 40, 11.2.1989, p.12).

[50] ISPRA (Italian Institute for Environmental Protection and Research), Study for the development of European Eco-label criteria for buildings, Second background report, March 2009.

[51] ISPRA (Italian Institute for Environmental Protection and Research), Draft Commission Decision on establishing the ecological criteria for the award of the Community Eco-Label for Buildings. Unpublished report, September 2009.

[52] Enea and F.IN.CO. (Federazione Industrie Prodotti Impianti e Servizi per le Costruzioni), Energia, Ambiente, Edificio - Dati, criticità e strategie per l'efficienza del sistema edificio. Il Sole 24 Ore, September 2004 (in Italian).

[53] Casals XG. Analysis of building energy regulation and certification in Europe: Their role, limitations and differences. Energy and Buildings 2006;38:381-392.

[54] Pérez-Lombard L, Ortiz J, González R, Maestre IR. A review of benchmarking, rating and labelling concepts within the framework of building energy certification schemes. Energy and Buildings 2009; 41:272-278.

[55] Rey FJ, Velasco E, Varela F. Building Energy Analysis (BEA): A methodology to assess building energy labelling. Energy and Buildings 2007;39:709-716.

[56] Decreto legislativo 19 agosto 2005, n. 192, "Attuazione della direttiva 2002/91/CE sul rendimento energetico in edilizia". (in Italian)

[57] Ilomäki A. https://www.cen.eu/cen/Sectors/../Construction/.../Session422TC350AI.pdf. "How will CEN TCs proceed?” - CEN CSN Conference 'Construction Standards: 2010 - 2015'.

[58] Zabalza Bribián I, Aranda Usón A, Scarpellini S. Life cycle assessment in buildings: State-of-the-art and simplified LCA methodology as a complement for building certification. Building and Environment 2009;44:2510-2520.

[59] Kotaji S, Schuurmans A, Edwards S. (edited by). Life-Cycle Assessment in Building and Construction: A StateOf-The-Art Report of Setac Europe, Setac-Europe, 2003. 
[60] ISO 21930:2007. Building construction - Sustainability in building construction - Environmental declaration of building products. Geneva: International Organization for Standardization, 2007.

[61] ISO 14025:2006. Environmental labels and declarations -- Type III environmental declarations - Principles and procedures. Geneva: International Organization for Standardization, 2006.

[62] ISO 14040:2006. Environmental management - Life cycle assessment - Principles and framework. Geneva: International Organization for Standardization, 2006.

[63] ISO 14044:2006. Environmental management - Life cycle assessment - Requirements and guidelines. Geneva: International Organization for Standardization, 2006. 